九州大学学術情報リポジトリ

Kyushu University Institutional Repository

Effects of Rheologic Conditions in the Culture Medium on the Autotrophic Production of Poly(D-3-hydroxybutyric Acid) in an Air-lift Fermentor

Taga, Naohiko

Department of Food Science and Technology, Faculty of Agriculture, Kyushu University

Tanaka, Kenj i

Department of Food Science and Technology, Faculty of Agriculture, Kyushu University

Ishizaki, Ayaaki

Department of Food Science and Technology, Faculty of Agriculture, Kyushu University

https://doi.org/10.5109/24106

出版情報：九州大学大学院農学研究院紀要. 40 (1/2)，pp. 197-207，1995-12. Kyushu University バージョン：

権利関係 : 


\title{
Effects of Rheologic Conditions in the Culture Medium on the Autotrophic Production of Poly-( D-3-hydroxybutyric Acid) in an Air-lift Fermentor
}

\author{
Naohiko Taga, Kenji Tanaka and Ayaaki Ishizaki \\ Department of Food Science and Technology, Faculty of Agriculture, \\ Kyushu University, Fukuoka 812-81, Japan \\ (Received July 31, 1995)
}

\begin{abstract}
The effects of rheological changes in the culture medium, caused by addition of sodium carboxymethylcellulose (CMC), on the autotrophic production of poly-(n-3-hydroxybutyric acid) $[\mathrm{P}(3 \mathrm{HB})]$ by Alcaligenes eutrophus was investigated in an air-lift fermentor. Addition of $0.05 \% \mathrm{CMC}$ increased $\mathrm{P}(3 \mathrm{HB})$ productivity to twice as in the control culture. The effect of $\mathrm{CMC}$ on the volumetric mass transfer coefficient, $\left(K_{\mathrm{I}} \alpha\right)$ and the relationship between $K_{\mathrm{l}} a$ and $\mathrm{P}(3 \mathrm{HB})$ productivity were investigated. The production of $\mathrm{P}(3 \mathrm{HB})$ rate was not correlated with $K_{\mathrm{L}} a$, when $K_{\mathrm{L}} a$ was measured by the sulfite oxidation method, but it was correlated with $K_{\mathrm{l}} a$, when $K_{1} a$ was measured by the static method. Thus, the sulfite oxidation method was unsuitable for measurements of the $K_{\mathrm{L}} a$ of this system.
\end{abstract}

\section{INTRODUCTION}

Polyhydroxyalkanoic acid (PHA) has potential utility as a raw material for the synthesis of biodegradable plastics (Anderson et al. 1990). A hydrogen-oxidizing bacterium, Alcaligenes eutrophus, is able to grow using hydrogen, oxygen and carbon dioxide under autotrophic culture conditions. The microorganism accumulates poly-(D-3hydroxybutyric acid) [P(3HB)], which is one type of PHA under nutrient- or oxygenlimited conditions. Production of $\mathrm{P}(3 \mathrm{HB})$ from carbon dioxide could contribute to the solution of two environmental pollution problems simultaneously: the elevation of the concentration of carbon dioxide in the atmosphere and the disposal of non-degradable plastic waste. However, for the practical application of the production of $\mathrm{P}(3 \mathrm{HB})$ from carbon dioxide by $A$. eutrophus, the danger of a substrate-gas explosion needs to be eliminated from the culture system. To avoid such a gas explosion, the concentration of oxygen (v/v) in the gas phase should be maintained below 6.9\% (Ishizaki et al. 1993). Unfortunately, the oxygen transfer rate in culture systems becomes very small at such low concentrations of oxygen, with a serious resultant decrease in biomass productivity. Furthermore, a high concentration of $\mathrm{P}(3 \mathrm{HB})$ cannot be achieved if the exponential growth of cells ceases at when the concentration of cells is still low as a consequence of oxygen limitation: the $\mathrm{P}(3 \mathrm{HB})$ production rate decreases with the increased accumulation of $\mathrm{P}(3 \mathrm{HB})$ in the cells and eventually ceases when the cell content of $\mathrm{P}(3 \mathrm{HB})$ reaches about $90 \%$ by weight. To solve these problems, we developed a two-stage culture method that consists of a heterotrophic culture system for cell growth and an autotrophic culture system for production of $\mathrm{P}$ (3HB) (Tanaka et al. 1994).

In recent years, the air-lift fermentor has often been used instead of the traditional stirred-tank fermentor. Since the air-lift fermentor does not require mechanical agitation, consumption of energy is very low as compared to that by a stirred-tank fermentor. 
Moreover, an air-lift fermentor has no sealed junction so that it is easy to avoid contamination. Air-lift fermentors are now used for production of antibiotics in some cases. During fermentation by filamentous fungi that produce antibiotics, the medium sometimes becomes very viscous (König et al. 1982). The effects of high-viscosity medium on the characteristics of air-lift fermentors have been reported (Kennard et al. 1991). In the present study, carboxymethylcellulose (CMC) was used to increase the viscosity of the medium. Addition of $\mathrm{CMC}$ causes drastic changes in the parameters of a culture system, such as the flow pattern, mixing time, gas hold-up, and/or mass transfer of oxygen. In particularly, many authors have reported that the gas hold-up is increased by the addition of CMC (Schumpe et al. 1982, Kennard et al. 1991 and Deckwer et al. 1993). Since the increase in gas hold-up is expected to increase the mass transfer of substrate gasses, $\mathrm{P}(3 \mathrm{HB})$ productivity during autotrophic fermentation might be expected to be increased.

In this study, we investigated the use of an air-lift fermentor for $\mathrm{P}(3 \mathrm{HB})$ production by $A$. eutrophus under autotrophic condition. The effects of rheological changes in the culture medium caused by addition of $\mathrm{CMC}$ on $\mathrm{P}(3 \mathrm{HB})$ productivity in the air-lift fermentor were also investigated.

\section{MATERIALS AND METHODS}

\section{Microorganism}

Alcaligenes eutrophus ATCC $17697^{\mathrm{T}}$ was used throughout this study.

\section{Compositions of media}

The medium used for the stock culture, stored at $-80^{\circ} \mathrm{C}$, and the refreshed culture consisted of meat extract, $7.0 \mathrm{~g}$; polypeptone, $10.0 \mathrm{~g}$; and $\mathrm{NaCl}, 5 \mathrm{~g}$ in $1 l$ of tap water. The $\mathrm{pH}$ was adjusted to 6.8 with $1 \mathrm{~N} \mathrm{NaOH}$. The medium for the preculture consisted of $\left(\mathrm{NH}_{4}\right)_{2} \mathrm{SO}_{4}, 1.0 \mathrm{~g} ; \mathrm{KH}_{2} \mathrm{PO}_{4}, 0.5 \mathrm{~g} ; \mathrm{MgSO}_{4} \cdot 7 \mathrm{H}_{2} \mathrm{O}, 0.2 \mathrm{~g} ; \mathrm{CaSO}_{4} \cdot 2 \mathrm{H}_{2} \mathrm{O}, 5.0 \mathrm{mg}$; fructose $10.0 \mathrm{~g}$ and $1 \mathrm{ml}$ of a solution of trace elements in $1 l$ of distilled water. The $\mathrm{pH}$ was adjusted to 6.8 with $1 \mathrm{~N} \mathrm{KOH}$. The solution of trace elements consisted of $\mathrm{CoCl}_{2}, 119 \mathrm{mg}$; $\mathrm{FeSO}_{4} \cdot 7 \mathrm{H}_{2} \mathrm{O}, 16.2 \mathrm{~g} ; \mathrm{NiCl}_{2} \cdot 6 \mathrm{H}_{2} \mathrm{O}, 118 \mathrm{mg} ; \mathrm{CrCl}_{3} \cdot 6 \mathrm{H}_{2} \mathrm{O}, 153 \mathrm{mg} ; \mathrm{CuSO}_{4} \cdot 5 \mathrm{H}_{2} \mathrm{O}, 156 \mathrm{mg}$ and citric acid, $15.6 \mathrm{~g}$ in $100 \mathrm{ml}$ of $1 \mathrm{~N} \mathrm{HCl}$. For autotrophic cultures, the mineral medium containing without a source of organic carbon was used.

\section{Cultivation system}

Figure 1 shows a schematic diagram of the cultivation system used for this study. The culture system was a based on the recycled-gas closed-circuit culture system (Ishizaki et al., 1990). For maintainance of a low concentration of oxygen, to eliminate the danger of a gas explosion, we used the substrate-gas feeding system with a gas composition controller that has been developed by the Research and Development Institute of Saibu Gas Co. Ltd., (Fukuoka, Japan). The system consisted of two gas cylinders with high pressure tolerance. The two gas cylinders contained $99.9 \%$ hydrogen and $50 \%$ oxygen plus $50 \%$ carbon dioxide, respectively, at pressures above $2.0 \times 10^{3} \mathrm{kPa}$. The pressure in the cylinders was reduced to about $30 \mathrm{kPa}$ by a pressure regulator, then 


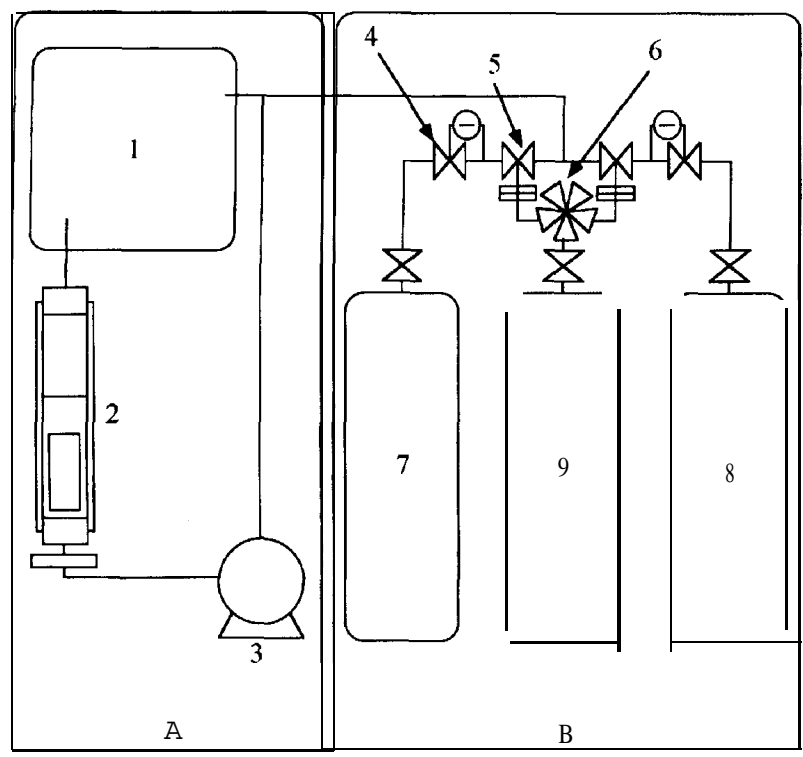

Fig. 1. Schematic diagram of the autotrophic culture system. A: Recycled-gas closed-circuit culture system. B: Substrategas feeding system with gas composition controller. 1: Gas reservoir. 2: Air-lift fermentor. 3: Blower. 4: Pressure regulator. 5: Valve driven by pressured nitrogen gas. 6: Five-direction valve with timer control. 7: Gas cylinder containing 99.9\% hydrogen. 8: Gas cylinder containing $50 \%$ carbon dioxide and $50 \%$ oxygen. 9: Gas cylinder containing $99.9 \%$ nitrogen.

the substrate gasses were supplied to the fermentor. The ratio of the supplied gasses could be controlled by changing the time, set by a control timer for opening and closing the valves. The valves were operated by nitrogen at high pressure to avoid a fire due to electric sparks in the substrate-gas feeding line. Figure 2 shows the air-lift fermentor and its dimensions are given in Table 1. To obtain high mass transfer via formation of small bubbles, a sintered stainless steel sparger (pore size, $10 \mu \mathrm{m}$; diameter, $12 \mathrm{~mm}$; length, 20 $\mathrm{mm}$ ) was installed at the bottom of the reactor (Okabe et al. 1993).

\section{Cell culture}

The cells were cultured by a two-stage method (Tanaka et al. 1994). First, one loop of the stock culture was inoculated into $5 \mathrm{ml}$ of nutrient-rich medium in a test tube and incubated at $30^{\circ} \mathrm{C}$ for $12 \mathrm{~h}$ with shaking. Two milliliters of the culture broth were then inoculated to $20 \mathrm{ml}$ of fructose medium in a 500 -ml shaking flask and incubated at $30{ }^{\circ} \mathrm{C}$ for $6 \mathrm{~h}$. Ten $\mathrm{ml}$ of the resultant broth were inoculated into $100 \mathrm{ml}$ of fructose medium in a 200-ml stirred jar-fermentor and cultivation was continued until the carbon source was exhausted. They were then pelleted by centrifugation and washed twice with the fresh mineral medium. The cells were resuspended in $150 \mathrm{ml}$ of mineral medium for 


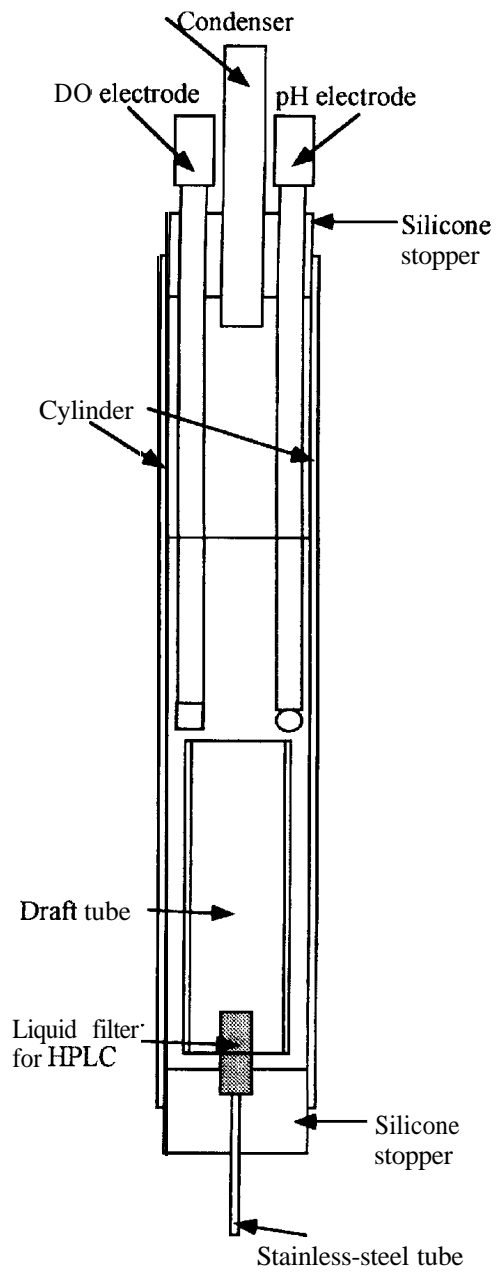

Fig. 2. Schematic diagram of air-lift fermentor.

Table 1. Dimensions of the air-lift fermentor

Reactor:

toral volume

total length

Cylindrical part:

length

inner diameter

diameter of draft tube

Sparger:

length of draft, tube
$350 \mathrm{ml}$

$350 \mathrm{~mm}$

$300 \mathrm{~mm}$

$40 \mathrm{~mm}$

$3 \mathrm{omm}$

$100 \mathrm{~mm}$

pore size

$10 \mu \mathrm{m}$ 
autotrophic culture in the air-lift fermentor.

\section{Culture conditions}

The working volume of the air-lift fermentor was $150 \mathrm{ml}$. The $\mathrm{pH}$ of the culture liquid was maintained at 6.8 by automatic addition of a $2.5 \%$ solution of ammonia water and the temperature was kept at 30 "C. The feeding rate of the substrate gas mixture was $2 \mathrm{l} / \mathrm{min}$, which was equivalent to a superficial gas velocity of $2.62 \mathrm{~cm} / \mathrm{s}$. The composition of the substrate mixture of carbon dioxide, hydrogen and oxygen was maintained at $10: 85: 5$ $(\mathrm{v} / \mathrm{v})$ by the substrate gas feeding system with the gas composition controller.

\section{Analytical methods}

The composition of the gas phase was analyzed with a gas chromatograph (GC-8A; Shimadze Seisakusyo Co. Ltd., Tokyo, Japan) equipped with a column (4 mm i.d. $\times 6 \mathrm{~m})$ into which molecular sieve 5A and Porapack Q has been packed (Morinaga et al. 1978). Dissolved oxygen (DO) tension in the culture broth was determined with a membrane electrode (S-Type; Able Co. Ltd., Tokyo, Japan). The concentration of cells was measured by converting the absorbance of the broth at $562 \mathrm{~nm}$ to dry cell weight (DCW) by reference to a previously prepared calibration curve. Protein in the culture broth was quantitated by the Biuret method (Herbert et al. 1971) with bovine serum albumin (SIGMA Co. Ltd., St. Louis, U.S.A.) as the standard. The concentration of P(3HB) was determined by gas chromatography (Braunegg et al. 1978).

\section{Measurements of viscosity, gas hold-up and volumetric mass transfer coefficient}

The viscosity of media was measured by Ostwald's method (Tanford et al. 1956). The gas hold-up in the air-lift fermentor was measured as described by Russel et al. (1993). The gas hold-up was determined by measuring the height of the aerated liquid and calculating the hold up according to the following equation:

$$
\varepsilon=\left(H_{D}-H_{L}\right) / H_{i}
$$

where $\varepsilon=$ overall gas hold up $(-) ; H_{,},=$height of gas-liquid dispersion (m); and $H_{L}=$ ungassed liquid height $(\mathrm{m})$.

Volumetric mass transfer coefficients $\left(K_{\mathrm{l}} a\right)$ were measured by using the sulfite oxidation method (Cooper et al. 1944) and the static method (Wise 1951).

\section{RESULTS AND DISCUSSION}

\section{Effects of the addition of CMC on viscosity and gas hold-up}

The viscosity of the medium is an important physical property in the air-lift fermentor, in particular because it has a considerabe effect on $K_{1}, a$, the mixing time and the gas hold-up. In general, very high viscosity has diverse effects on the mass transfer of the substrate gasses into a culture system. The viscosity of the medium can be increased by the addition of CMC. Figure 3 shows the changes in the viscosity of the present 
medium at various concentrations of CMC. The results show that addition of a small amount of CMC increased the viscosity considerably. The gas hold-up is an important parameter related to the gas-supply capacity of the air-lift fermentor. The gas hold-up is equivalent to the reaction area of the gas-liquid phase in the fermentor. Figure 4 shows the effects of the concentration of CMC on the gas hold-up in the air-lift fermentor. At a superficial gas velocity of $2.62 \mathrm{~cm} / \mathrm{s}$, the gas hold-up was increased by addition of CMC up to $0.1 \%$ and then it decreased with further increases in levels of CMC. From this result, we expected that addition of $\mathrm{CMC}$ up to $0.1 \%$ would increase $\mathrm{P}(3 \mathrm{HB})$ productivity.

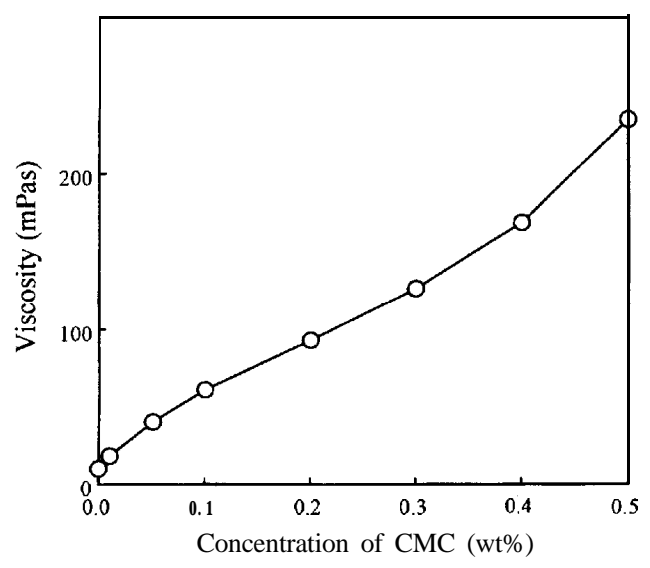

Fig. 3. Effects of the concentration of $\mathrm{CMC}$ on the viscosity of the medium at $30^{\circ} \mathrm{C}$

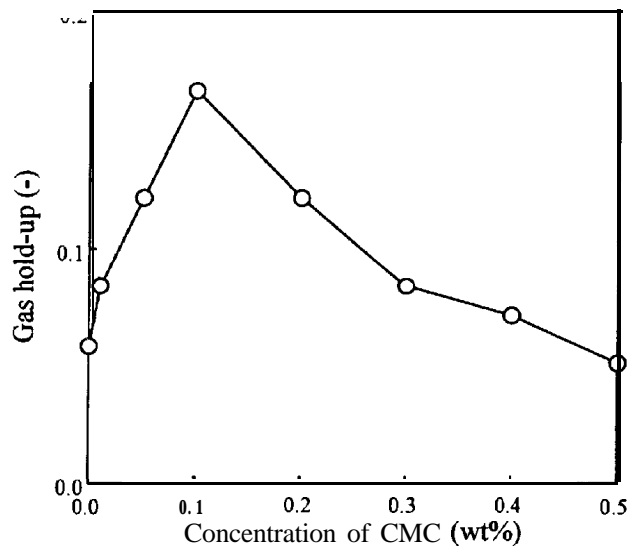

Fig. 4. Effects of the concentration of $\mathrm{CMC}$ on gas hold-up in the air-lift fermentor at $30{ }^{\circ} \mathrm{C}$ at a superficial gas velocity of $2.62 \mathrm{~cm} / \mathrm{s}$. 


\section{Experimental cultures}

Figure 5a shows the time course of the autotrophic culture of A. eutrophus without addition of CMC, as a control culture. The concentration of dissolved oxygen decreased to below the lower limit for detection by the DO electrode after $6 \mathrm{~h}$. However, the protein concentration gradually increased until $33 \mathrm{~h}$ of cultivation and then remained at $10 \mathrm{~g} \cdot l^{1}$. After $33 \mathrm{~h}$, DCW and the concentration of $\mathrm{P}(3 \mathrm{HB})$ increased linearly to reach $60.0 \mathrm{~g} \cdot l^{-1}$ and $49.2 \mathrm{~g} \cdot l^{-1}$, respectively, by $120 \mathrm{~h}$ of cultivation. During the $\mathrm{P}(3 \mathrm{HB})$ accumulation phase from $33 \mathrm{~h}$ to $120 \mathrm{~h}$, the $\mathrm{P}(3 \mathrm{HB})$ productivity was $0.550 \mathrm{~g} \cdot l^{1} \cdot \mathrm{h}^{1}$. The final $\mathrm{P}(3 \mathrm{HB})$ content of the cells was $82.0 \%(\mathrm{w} / \mathrm{w})$.

We confirmed that our strain of $A$. eutrophus could not utilize CMC as a carbon source (data not shown). Figure $5 \mathrm{~b}$ shows the time course of fermentation with $0.05 \%$ $\mathrm{CMC}$ in the culture medium. After $9 \mathrm{~h}$ of cultivation, the extent of the decrease in the dissolved oxygen concentration was lower than that in the control culture. The protein concentration increased slowly as compared that in the control culture until $42 \mathrm{~h}$ of cultivation. After $42 \mathrm{~h}$, DCW and the concentration of $\mathrm{P}(3 \mathrm{HB})$ increased linearly to 69.3 $\mathrm{g} \cdot l^{1}$ and $56.4 \mathrm{~g} \cdot l^{-1}$, respectively, at $92 \mathrm{~h}$ of cultivation. In the P(3HB) accumulation phase from $42 \mathrm{~h}$ to $92 \mathrm{~h}$, the $\mathrm{P}(3 \mathrm{HB})$ productivity was $1.02 \mathrm{~g} \cdot l^{1} \cdot \mathrm{h}^{-1}$. The final $\mathrm{P}(3 \mathrm{HB})$ content of the cells was $81.4 \%(\mathrm{w} / \mathrm{w})$.

Figure $5 \mathrm{c}$ shows the time course of fermentation in the presence of $0.1 \% \mathrm{CMC}$. After $3 \mathrm{~h}$ of cultivation, the decrease in dissolved oxygen concentration was greater than that in the control culture. The protein concentration slowly increased as compared to the control culture until $60 \mathrm{~h}$ of cultivation. The result of this last experiment was different from those of the first two culture experiments and in that the accumulation of $\mathrm{P}(3 \mathrm{HB})$ started simultaneously with cell growth. After $30 \mathrm{~h}, \mathrm{DCW}$ and the concentration of P(3HB) increased linearly to $58.8 \mathrm{~g} \cdot l^{-1}$ and $46.2 \mathrm{~g} \cdot l^{-1}$, respectively, until $84 \mathrm{~h}$. During the

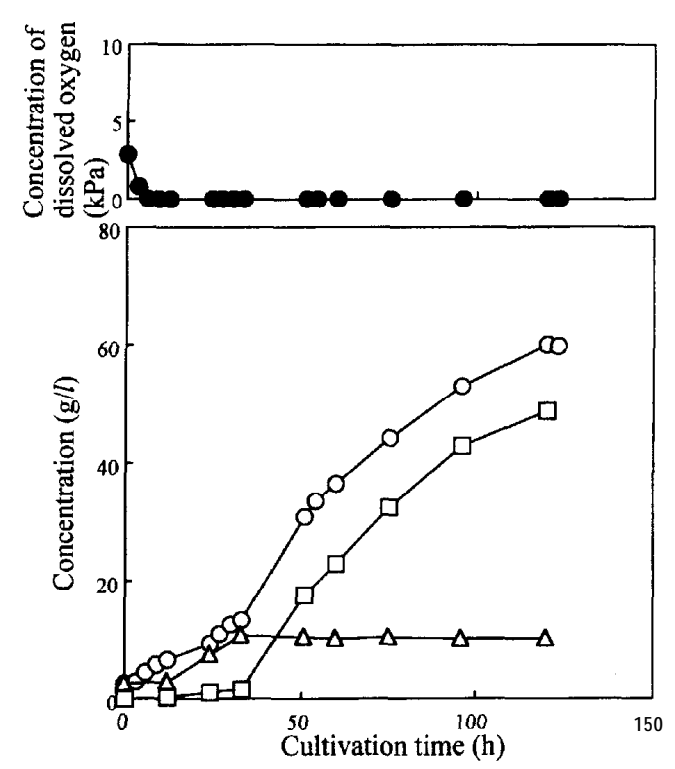

Fig 5a.

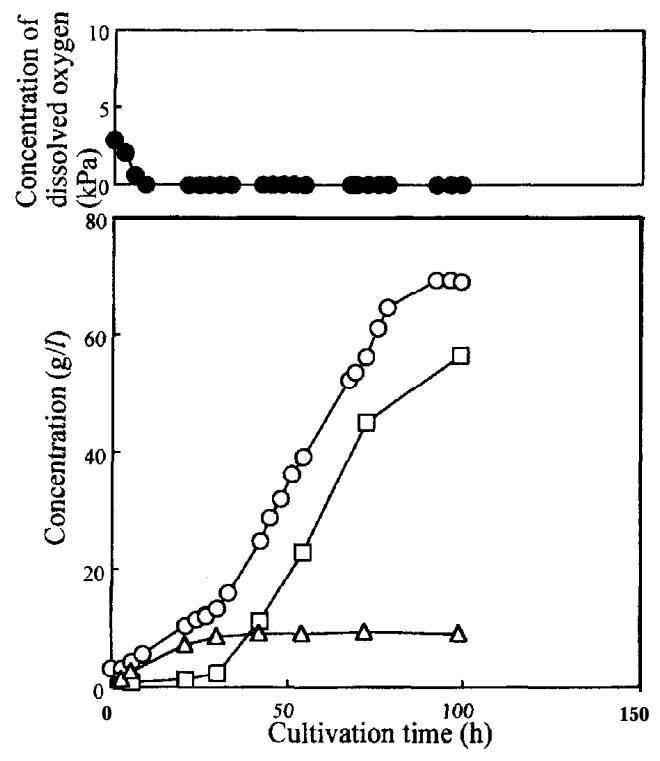

Fig. 5b. 


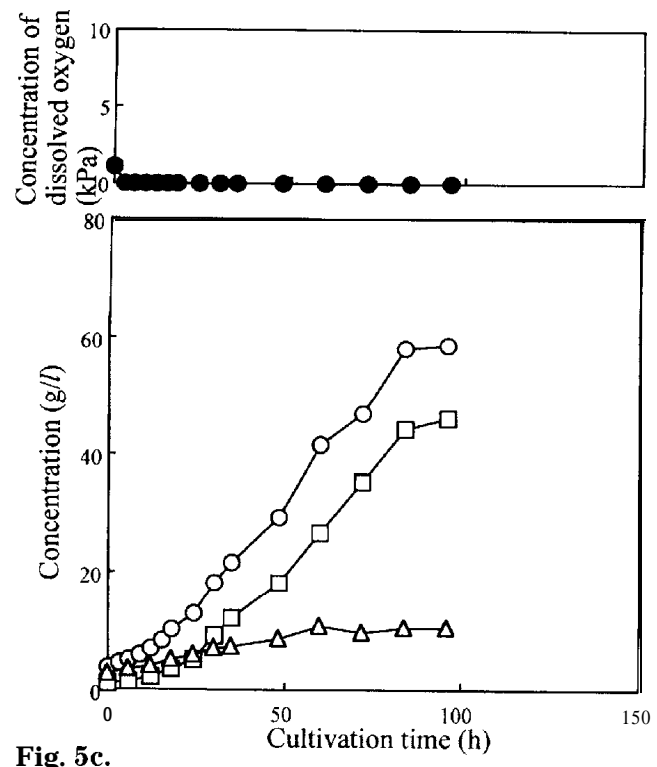

Fig. 5. Time course of an autotrophic culture of A. eutrophus in the air-lift fermentor. a, $0 \%$ $\mathrm{CMC}$ medium as control; $\mathrm{b}, 0.05 \% \mathrm{CMC}$ medium ; $\mathrm{C}, 0.1 \%$ CMC medium. Symbols: $\bigcirc, D C W ; \square, P(3 H B) ; \triangle$, Protein.

$\mathrm{P}(3 \mathrm{HB})$ accumulation phase from $30 \mathrm{~h}$ to $84 \mathrm{~h}$, the $\mathrm{P}(3 \mathrm{HB})$ productivity was $0.743 \mathrm{~g} \cdot \mathrm{l}^{-1} \cdot \mathrm{h}^{-1}$. The final $\mathrm{P}(3 \mathrm{HB})$ content of the cells was $78.6 \%(\mathrm{w} / \mathrm{w})$. The $\mathrm{P}(3 \mathrm{HB})$ productivity during cultivation with $0.05 \% \mathrm{CMC}$ was about twice that in the control culture. Although the gas hold-up with the addition of $0.1 \% \mathrm{CMC}$ was higher than that with $0.05 \% \mathrm{CMC}, \mathrm{P}(3 \mathrm{HB})$ productivity of the culture with $0.1 \% \mathrm{CMC}$ was only about 1.4 times that of the control culture. The following experiment was carried out to investigate the effects of CMC in further detail.

\section{Volumetric mass transfer coefficient}

During autotrophic cultivation, $\mathrm{P}(3 \mathrm{HB})$ productivity depends on the volumetric mass transfer coefficient of the fermentor and the concentration of oxygen in the gas phase. Figure 6 shows the effect of the concentration of CMC on values of $K_{\mathrm{l}} a$ measured by the sulfite oxidation method and the static method. $K_{\mathrm{l}} a$ measured by the sulfite oxidation method decreased with increases in the concentration of CMC. With measurements by the static method, the maximum $K_{\mathrm{l}} a$ was obtained at $0.05 \% \mathrm{CMC}$. In the range of CMC concentrations from 0 to $0.05 \%$, the $K_{\mathrm{L}} a$ measured by the sulfite oxidation method was somewhat higher than that measured by the static method. It is generally known that certain surfactants, such as CMC, can affect sulfite oxidation. Figure 7 shows the relationship between the $\mathrm{P}(3 \mathrm{HB})$ production rate in the above cultivation experiments and values of $K_{a} a$ measured by the sulfite oxidation method and the static method. The correlation between the $\mathrm{P}(3 \mathrm{HB})$ production rate and the $K_{l} a$ measured by the static 


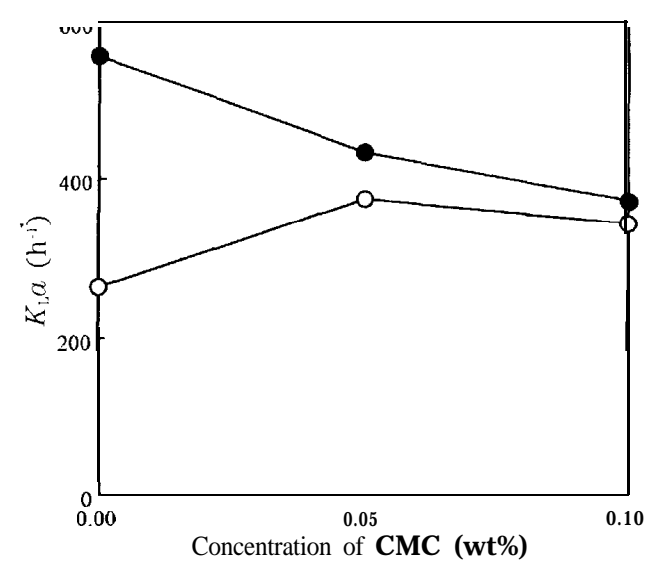

Fig. 6. $K_{1} a$ of air-lift fermentor at various concentrations of CMC. Symbols: $\bigcirc$, static method; , sulfite oxidation method.

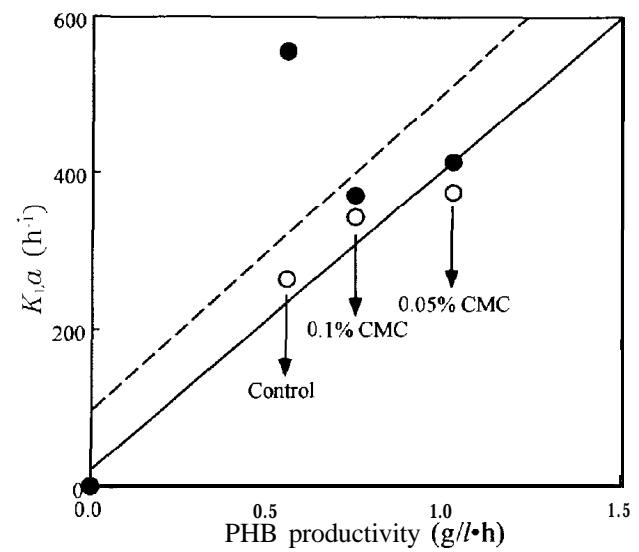

Fig. 7. Correlation between $\mathrm{P}(3 \mathrm{HB})$ productivity and $K_{\mathrm{L}} a$. Symbols: $\bigcirc$, static method; $\bigcirc$, sulfite oxidation method. Functions for correlations: static method, solid line, $\mathrm{y}=22.352+385.21 \mathrm{x}$ $\mathrm{R}^{\prime}=0.953$; sulfite oxidation method, dotted line, $y=98.601+409.45 \times R^{\prime}=0.554$.

method was very high. However, the correlation between the $\mathrm{P}(3 \mathrm{HB})$ production rate and the $K_{\mathrm{L}} a$ measured by the sulfite oxidation method was low. The flow characteristics of the aerated culture liquid with sodium sulfite were different from those of the culture medium that contained no sodium sulfite. The bubbles in the culture liquid with sodium sulfite seemed very small and the flow was homogeneous. Therefore, the gas hold-up in the presence of sodium sulfite was larger than that in the absence of sodium sulfite. 


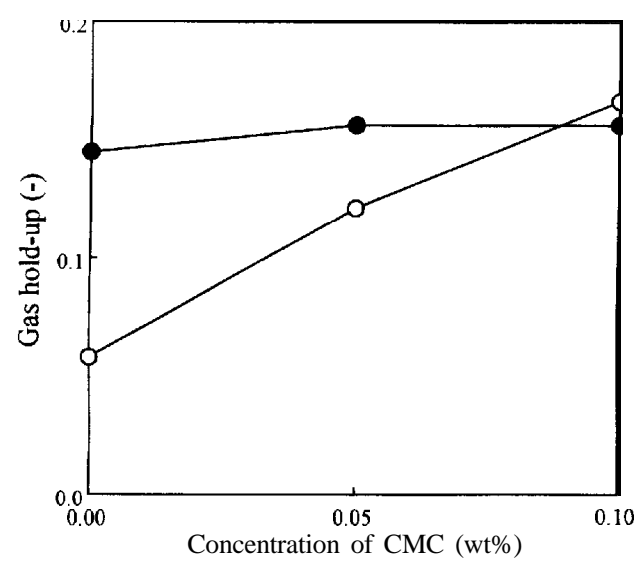

Fig. 8. Effects of addition of sodium sulfite on the gas hold-up in the air-lift fermentor. Symbols: $O$, medium without sodium sulfite; $\bigcirc$, medium with sodium sulfite.

Figure 8 shows the effects of the presence of sodium sulfite on the gas hold-up. Measurements of $K_{\mathrm{L}} a$ by the static method were made under the same gas hold-up conditions using the liquid without sodium sulfite. The results showed that the static method is more suitable for measurements of $K_{\mathrm{L}} a$ than the sulfite oxidation method in our system. However, there was a weak relationship between the $K_{\mathrm{L}} a$ measured by the static method and the gas hold-up. This result cannot be easily explained at present. It is possible that the size of bubbles in the liquid increased with the addition of CMC and that these large bubbles increased the gas hold-up. As the size of bubbles increases, the gasliquid surface would become smaller, and then the $K_{\mathrm{L}} a$ measured by the static method might be reduced. However, since it is very difficult to determine the mean size of bubbles, it is hard to validate this assumption.

In conclusion, a laboratory-scale air-lift fermentor was used for autotrophic culture of A. eutrophus. The $\mathrm{P}(3 \mathrm{HB})$ production rate was increased by addition of $0.05 \% \mathrm{CMC}$. The $\mathrm{P}(3 \mathrm{HB})$ production rate was not correlated with the $K_{\mathrm{L}} a$ measured by the sulfite oxidation method but was correlated with the $K_{1} a$ measured by the static method. We are now investigating a culture system with higher $\mathrm{P}(3 \mathrm{HB})$ productivity as a consequence of an increase of the protein concentration during the first stage of the two-stage culture system.

\section{ACKNOWLEDGMENTS}

The authors are grateful to professor Mitsuyasu Okabe of Shizuoka University for his guidance on the air-lift fermentor. We express our appreciation to the members of the Research and Development Institute of Saibu Gas Co. Ltd., for their assistance and advice related to development of the substrate-gas feeding system with the gas composition 
controller employed in this study.

\section{REFERENCES}

Anderson, A. and E.A. Dawes 1990 Occurrence, metabolic role, and industrial use of bacterial polyhydroxyalcanoates. Microbiol. Rev., 54: 450-472

Braunegg, G., B. Sonnleitner and R.M. Lafferty 1978 A rapid gas chromatographic method for the determination of poly-b-hydroxybutyric acid in microbial biomass. Eur. J. Appl. Microbiol., 6: 29-37

Cooper, C.M., G.A. Fernstrom and S.A. Miller 1944 Performance of agitated gas-liquid contacters. Ind. Eng. Chern., 36: 504-509

Deckwer, W.D. and A. Schumpe 1993 Improved tools for bubble column reactor design and scale-up. Chem. Eng.Sci, 48: 889-911

Herbert, D., J. Phipps and R.E. Strange 1971 Chemical analysis of microbial cells: determination of protein. In "Methods in Microbiology", Vol. 5A, ed. by J. R. Norris and D. W. Ribbons, Academic Press, London and New York, pp. 243-249.

Ishizaki, A. and K. Tanaka 1990 Batch culture of Alcaligenes eutrophus ATCC 17697" using recycled gas closed circuit culture system. J.Ferment.Bioeng., 69: 170-174

Ishizaki, A., K. Tanaka, T. Takeshita, T. Kanemaru, T. Shimoji and T. Kawano 1993 Equipment and operation for fermentative Production of $\mathrm{P}(3 \mathrm{HB})$ using gaseous substrate to guarantee safety from explosion. J.Chem. Eng.Japan., 26: 224-226

Kennard, M. and M. Janekeh 1991 Two- and three-phase mixing in a concentric draft tube gas-lift fermentor. Biotechnol. and Bioeng., 38: 1261-1270

Kodama, T., Y. Igarashi and Y. Minoda 1975 Isolation and culture conditions of a bacterium grown on hydrogen and carbon dioxide. Agr. Biol.Chem, 39: 77-82

König, B., K. Schügerl and Ch. Seewald 1982 Strategies for penicillin fermentation in a tower-loop reactor. Biotechnol.Bioeng., 24: 259-280

Morinaga, Y., S. Yamanaka, A. Ishizaki and Y. Hirose 1978 Growth characteristics and cell composition of Alcaligenes eutrophus in chemostat culture. Agr. Biol. Chem, 42: 439-444

Okabe, M., N. Ohta and Y.S. Park 1993 Itaconic acid production in an air-lift bioreactor using a modified draft tube. J.Ferment. Bioeng., 76: 117-122

Russel, A.B., C.R. Thomas and M.D. Lilly 1993 The influence of vessel height and top-section size on the hydrodynamic characteristics of airlift fermentors. Biotechnol. Bioeng., 43: 69-76

Schumpe, A. and W.D. Deckwer 1982 Gas holdups, specific interfacial areas, and mass transfer coefficients of aerated carboxymethylcellulose solutions in a bubble column. Ind. Eng.Chem. Process Des. Den., 21: 706-711

Tanaka, K. and A. Ishizaki 1994 Production of poly-r-3-hydroxybutyric acid from carbon dioxide by a twostage culture method by Alcaligenes eutrophus ATCC 17697. J.Ferment. Bioeng., 77: 425-427

Tanford, C. and J.G. Buzzell 1956 The viscosity of aqueous solutions of bovine serum albumin between $\mathrm{pH}$ 4.3 and 10.5. J.Phys. Chem.,

W i s W.S. 1951 The measurement of the aeration of culture media. J.Gen. Microbiol, 5: 167-177 